\title{
Arginine deiminase augments the chemosensitivity of argininosuccinate synthetase-deficient pancreatic cancer cells to gemcitabine via inhibition of NF-KB signaling
}

Jiangbo Liu ${ }^{1,2}$, Jiguang $\mathrm{Ma}^{3}$, Zheng $\mathrm{Wu}^{1}$, Wei $\mathrm{Li}^{1}$, Dong Zhang ${ }^{1}$, Liang Han ${ }^{1}$, Fengfei Wang ${ }^{4}$, Katie M Reindl ${ }^{5}$, Erxi $\mathrm{Wu}^{4}$ and Qingyong Ma ${ }^{1 *}$

\begin{abstract}
Background: Pancreatic cancer is a leading cause of cancer-related deaths in the world with a 5-year survival rate of less than $6 \%$. Currently, there is no successful therapeutic strategy for advanced pancreatic cancer, and new effective strategies are urgently needed. Recently, an arginine deprivation agent, arginine deiminase, was found to inhibit the growth of some tumor cells (i.e., hepatocellular carcinoma, melanoma, and lung cancer) deficient in argininosuccinate synthetase (ASS), an enzyme used to synthesize arginine. The purpose of this study was to evaluate the therapeutic efficacy of arginine deiminase in combination with gemcitabine, the first line chemotherapeutic drug for patients with pancreatic cancer, and to identify the mechanisms associated with its anticancer effects.

Methods: In this study, we first analyzed the expression levels of ASS in pancreatic cancer cell lines and tumor tissues using immunohistochemistry and RT-PCR. We further tested the effects of the combination regimen of arginine deiminase with gemcitabine on pancreatic cancer cell lines in vitro and in vivo.

Results: Clinical investigation showed that pancreatic cancers with reduced ASS expression were associated with higher survivin expression and more lymph node metastasis and local invasion. Treatment of ASS-deficient PANC-1 cells with arginine deiminase decreased their proliferation in a dose- and time-dependent manner. Furthermore, arginine deiminase potentiated the antitumor effects of gemcitabine on PANC-1 cells via multiple mechanisms including induction of cell cycle arrest in the S phase, upregulation of the expression of caspase-3 and 9, and inhibition of activation of the NF-KB survival pathway by blocking NF-KB p65 signaling via suppressing the nuclear translocation and phosphorylation (serine 536) of NF-KB p65 in vitro. Moreover, arginine deiminase can enhance antitumor activity of gemcitabine-based chemotherapy in the mouse xenograft model.
\end{abstract}

Conclusions: Our results suggest that arginine deprivation by arginine deiminase, in combination with gemcitabine, may offer a novel effective treatment strategy for patients with pancreatic cancer and potentially improve the outcome of patients with pancreatic cancer.

\section{Background}

Pancreatic cancer is the fourth most common cause of cancer-related deaths in western countries, with a median overall survival of less than 6 months and a 5 -year survival rate of less than $6 \%[1,2]$. In 2014 , it is estimated

\footnotetext{
* Correspondence: qyma56@mail.xjtu.edu.cn

'Department of Hepatobiliary Surgery, First Affiliated Hospital, Medical college of Xi'an Jiaotong University, 277 West Yanta Road, Xi'an, Shaanxi 710061, China

Full list of author information is available at the end of the article
}

that 46,420 Americans will be newly diagnosed with pancreatic cancer and 39,590 will die of the disease [2]. Because of aggressive growth, early local invasion, and tumor metastasis, the majority of patients (over 80\%) are diagnosed at an unresectable stage [3]. Gemcitabine (2'-Deoxy-2', 2'-difluorocytidine; GEM)-based chemotherapy has been used as a palliative cancer treatment for more than two decades and is currently the first-line chemotherapeutic agent for treatment of patients with

\section{Ciomed Central}

(c) 2014 Liu et al.; licensee BioMed Central Ltd. This is an Open Access article distributed under the terms of the Creative Commons Attribution License (http://creativecommons.org/licenses/by/4.0), which permits unrestricted use, distribution, and reproduction in any medium, provided the original work is properly credited. The Creative Commons Public Domain Dedication waiver (http://creativecommons.org/publicdomain/zero/1.0/) applies to the data made available in this article, unless otherwise stated. 
advanced pancreatic cancer. However, given that pancreatic cancer is highly resistant to chemotherapeutic agents, a number of clinical trials show that GEM alone or in combination with other regimens such as cetuximab, or S-1 [an oral fluorourail (FU) derivative], does not improve the overall survival of pancreatic cancer patients [4-6]. Therefore, it is imperative to develop novel therapeutic strategies.

Arginine can be synthesized from citrulline by the enzymes of the urea cycle, namely argininosuccinate synthetase (ASS) and argininosuccinate lyase (ASL), and is, therefore, regarded as a nonessential amino acid for humans and mice [7]. Some human cancers, such as melanoma, lung cancer, renal cell carcinomas, and hepatocellular carcinomas [8-10] do not express ASS and are highly sensitive to arginine deprivation via arginine deiminase (ADI). ADI is an arginine deprivation agent capable of degrading arginine into citrulline [11,12]. ADI eliminates intracellular arginine by reducing the extracellular and plasma levels, thereby producing an arginine shortage in the ASS-deficient tumor cells, but not affecting cells that express ASS $[10,13,14]$. A recent study demonstrated that several pancreatic cancer cells exhibit reduced ASS expression, and the growth of these cells in vitro and in vivo is inhibited via arginine elimination using a polyethylene glycol-modified ADI (PEG-ADI) [15].

GEM, a pyrimidine-based antimetabolite, has been used for the treatment of pancreatic cancer for two decades $[16,17]$. It has been demonstrated that GEM activates the $\mathrm{S}$-phase checkpoint via inhibition of DNA replication [18]. As documented above, pancreatic cancers are often resistant to GEM through several molecular mechanisms [19-24]. NF-kB plays a critical role in activating transcriptional events that lead to cell survival, and activation of this signaling pathway is associated with GEM chemoresistance in pancreatic cancer cells $[23,25,26]$. Agents that block NF- $\mathrm{kB}$ activation could reduce chemoresistance to GEM and may be used in combination with GEM as a novel therapeutic regimen for treating pancreatic cancer [27-30]. Previous research has demonstrated that arginine deprivation therapy and the associated agent ADI may be a promising therapy for pancreatic cancer [15]. However, whether ADI potentiates the anticancer activities of GEM in pancreatic cancer cells and its precise mechanisms are not clear.

In this study, we aimed to examine the effects and mechanisms of ADI alone and in combination with GEM on the survival of pancreatic cancer cells in vitro and in vivo in order to develop a novel effective therapeutic strategy for treating pancreatic cancer. Our results show that pancreatic cancer cells lacking ASS expression have high sensitivity to arginine deprivation by ADI. Further, when ADI was combined with GEM in ASS-negative pancreatic cancer cells, NF-kB signaling was suppressed and more cell death was induced in vitro and in vivo. Clinically, pancreatic cancer patients with reduced ASS expression may have shorter survival times.

\section{Methods}

\section{Reagents and chemicals}

Diamidino-2-phenylindole (DAPI), crystal violet, Dimethyl Sulfoxide (DMSO), methyl thiazolyl tetrazolium (MTT), propidium iodide (PI), and RNase were obtained from Sigma Chemical (St. Louis, MO, USA). Bicinchoninic acid (BCA) protein assay reagent was from Pierce Chemical (Rockford, IL, USA). The ADI gene was cloned from the $M$. arginini genomic DNA, and the $46 \mathrm{kDa}$ ADI recombinant protein (Additional file 1: Figure S1) was produced as previously described [31]. ADI activity was determined by measuring the formation of L-citrulline from L-arginine following a modified method using diacetyl monoxime thiosemicarbazide [32]. One unit of ADI activity is defined as the amount of enzyme catalyzing 1 $\mu \mathrm{mol}$ of $\mathrm{L}$-arginine to $1 \mu \mathrm{mol}$ of $\mathrm{L}$-citrulline per min under the assay conditions. Finally, the measured activity of the ADI was $30 \mathrm{U}$ per mg protein. GEM was purchased from Eli Lilly France SA (Fergersheim, France).

\section{Cell lines and cell culture}

Human primary pancreatic cancer cell lines MIA PaCa-2, PANC-1, and BxPC-3, and spleen metastatic pancreatic cancer cell line SW1990, breast cancer cell lines MDAMB-453, BT474, MDA-MB-231, and MCF-7, and hepatocellular carcinoma (HCC) cell lines HepG2 and MHCC97-H were all purchased from the American Type Culture Collection (ATCC). All cell lines were maintained in the recommended medium (HyClone, Logan, USA) containing 10\% heat-inactivated fetal bovine serum (HyClone) and $1 \%$ penicillin/streptomycin (HyClone) in a humidified $\left(37^{\circ} \mathrm{C}, 5 \% \mathrm{CO}_{2}\right)$ incubator. Plastic wares for cell culture were obtained from BD Bioscience (Franklin Lakes, NJ).

\section{Tissue samples and immunohistochemistry}

Thirty-seven paraffin-embedded pancreatic cancer tissues were obtained from the First Affiliated Hospital of Medical College, Xi'an Jiaotong University, between 2007 and 2010. The paraffin-embedded tissue samples were then sliced into consecutive 4- $\mu \mathrm{m}$-thick sections and prepared for immunohistochemical (IHC) studies. IHC staining was performed using an ultrasensitive SP-IHC kit (Beijing Zhongshan Biotechnology, Beijing, China), according to the manufacturer's protocol. Briefly, after dewaxing and rehydration, the antigen was heat-retrieved, endogenous peroxidase was quenched, and the sample was blocked with $10 \%$ BSA for $30 \mathrm{~min}$ at room temperature. The slides were then immersed in either primary anti-ASS1 (H231; Santa Cruz Biotechnology, Santa Cruz, CA, USA) or 
anti-survivin (N111; Bioworld, Minneapolis, USA) rabbit polyclonal antibodies overnight at $4^{\circ} \mathrm{C}$ in a humid chamber, followed by rinsing and incubating with the goat antirabbit secondary antibody kit. The slides were stained with the 3,3-diaminobenzidine tetrahydrochloride (DAB) kit (Beijing Zhongshan Biotechnology, Beijing, China) and were subsequently counterstained with hematoxylin. Two pathologists assessed the IHC results as described previously [33]. Finally, the images were examined under a light microscope (Olympus, Tokyo, Japan). The Ethical Review Board Committee of the First Affiliated Hospital of Medical College, Xi'an Jiaotong University, China, approved the experimental protocols and informed consent was obtained from each patient who contributed tissue samples.

\section{Reverse transcription-polymerase chain reaction (RT-PCR)} and quantitative-real time RT-PCR

Total RNA from cells was prepared using trizol (Invitrogen, Carlsbad, CA, USA) according to the manufacturer's protocol [34]. Subsequently, the total RNA was reversetranscribed into cDNA using a Takara Reverse Transcription Kit (Takara, Dalian, China) according to the manufacturer's recommendations. Reverse transcriptionpolymerase chain reaction (RT-PCR) was performed as previously described [35]. For quantitative-real time (qRT)-PCR reactions, $2 \mu \mathrm{L}$ of cDNA was mixed with a reaction mix containing $10 \mu \mathrm{L}$ of SYBR Green (Takara), $0.8 \mu \mathrm{L}$ of primers, and water for a total reaction volume of $20 \mu \mathrm{L}$. For detecting of ASS1, caspase-3, caspase-9, Bax, Bcl-2, and survivin at mRNA levels, the following gene specific primers (Beijing Dingguo Changsheng Biotechnology) were designed as follows:

ASS1-sense: 5'-AGTTCAAAAAAGGGGTCCCT-3', ASS1-antisense: 5'-TTCTCCACGATGTCAATACG-3'; Caspase-3-sense: 5'-GTAGAAGAGTTTCGTGAGTGC-3', Caspase-3-antisense: 5'-TGTCCAGGGATATTCCAG AG-3';

Caspase-9-sense: 5'-GCCATGGACGAAGCGGATCG GCGG-3',

Caspase-9-antisense: 5'-GGCCTGGATGAAGAAGA GCTTGGG-3';

Survivin-sense: 5'-TCCACTGCCCCACTGAGAAC-3', Survivin-antisense: 5'-TGGCTCCCAGCCTTCCA-3'; Bax-sense: 5'-GGCTGGACATTGGACTTC-3', Bax-antisense: 5'-AAGATGGTCACGGTCTGC-3'; Bcl-2-sense: 5'-GTGTGGAGAGCGTCAACC-3', Bcl-2-antisense: 5'-CTTCAGAGACAGCCAGGAG-3'; GAPDH-sense: 5'-CTCTGATTTGGTCGTATTGGG-3', GAPDH-antisense: 5'-TGGAAGATGGTGATGGGATT-3';

The number of specific transcripts detected was normalized to the level of GAPDH. Relative quantification of gene expression (relative amount of target RNA) was determined using the equation $2^{(-\Delta \Delta \mathrm{Ct})}$.

\section{Immunofluorescence}

Cells were grown on glass coverslips, fixed with $4 \%$ paraformaldehyde for $10 \mathrm{~min}$ at room temperature, and then incubated with or without (control) the primary antiASS (H231) antibody overnight; the coverslips were then washed and incubated with the appropriate secondary antibody conjugated with FITC for $1 \mathrm{~h}$ at room temperature. DAPI was used to stain the nuclei. The coverslips were mounted onto slides, and the cells were viewed for evaluating ASS expression using a Leica TCS-SP2 confocal scanning microscope (Leica, Heidelberg, Germany).

\section{Western blot analysis}

Total protein from pancreatic cancer tissues or cells was extracted following lysis in the RIPA lysis buffer (150 mM $\mathrm{NaCl}, 50 \mathrm{mM}$ Tris, 1\% NP-40, 0.25\% sodium deoxycholate, and $1 \mathrm{mM}$ EGTA) supplemented with the protease inhibitor cocktail (Sigma, St, Louis, USA) for $30 \mathrm{~min}$ [36]. The resulting debris was removed by centrifugation, and the supernatant containing the protein lysate was collected. For preparation of the nuclear extracts, cells in the control and experimental groups were treated for the indicated times, then incubated on ice for $30 \mathrm{~min}$ followed by preparation of the nuclear extracts using a nuclear extract kit (Pierce) according to the manufacturer's instructions. The cellular protein content was determined using the BCA kit (Beyotime Biotechnology, Nantong, China), and the cell lysates were separated on a 10\% SDS-PAGE gel followed by electro-transfer onto a Millipore PVDF membrane (Billerica, USA). After being blocked with 5\% nonfat milk in TBST, the membranes were incubated with the respective primary antibodies (pSTAT3 [Tyr705], totalSTAT3, p-ERK1/2 [Thr202/Tyr204], and ERK1/2 [all from Cell Signaling Technology, Beverly, USA]; p-Akt [Thr308], total-Akt, total NF-кB p65, caspase-3, caspase-9, XIAP, c-Jun, p21, p53, $\beta$-actin [all from Santa Cruz Biotechnology]; survivin, p-c-Jun [S73], p-NF-kB p65 [S536], lamin B1 [all from Bioworld]; cyclin D1 [Boster, Wuhan, China], and ASS1 [Proteintech, Chicago, USA]) at $4{ }^{\circ} \mathrm{C}$ overnight, followed by 1:2000 horseradish peroxidase (HRP)-conjugated secondary antibodies (anti-mouse, anti-rabbit, anti-goat; Santa Cruz Biotechnology) for $2 \mathrm{~h}$. Immunoreactive bands were visualized using an enhanced chemiluminescence kit (Millipore) and photographed by GeneBox analyzer (SynGene, UK). All analyses were performed in duplicate.

\section{Cell proliferation assay}

Cell proliferation was determined by the MTT uptake method. Following an overnight culture in a 96-well plate in $200 \mu \mathrm{L}$ of suitable medium, cells $\left(5 \times 10^{3} /\right.$ well $)$ 
were treated with varying concentrations of ADI (0-10 $\mathrm{mU} / \mathrm{mL})$, GEM $\left(0-10^{5} \mathrm{nM}\right)$, or both agents for the indicated time. Then, MTT $(5 \mathrm{mg} / \mathrm{mL})$ was added and incubation was continued for $4 \mathrm{~h}$, followed by termination of the reaction with $150 \mu \mathrm{L}$ of DMSO per well. Absorbance values were determined at $490 \mathrm{~nm}$ on a Dias automatic microwell plate reader (Dynatech Laboratories, Chantilly, USA), using DMSO as the blank and cells cultured in untreated medium as the control group. The cell viability index was calculated using the formula of $\mathrm{OD}_{\text {sample }} / \mathrm{OD}_{\text {control }} \times 100 \%$, while inhibition ratio calculated by formula of $\left(1-\mathrm{OD}_{\text {sample }} / \mathrm{OD}_{\text {control }}\right) \times 100 \%$. Each experiment was repeated three times.

\section{Colony formation assay}

Cells were seeded in a 6-well plate at a density of approximately $2.0 \times 10^{2}$ per well $(2 \mathrm{~mL})$ and allowed to attach for $24 \mathrm{~h}$. Next day, the adherent cells were treated with ADI $(0$, or $1.0 \mathrm{mU} / \mathrm{mL})$ or GEM $(0$ or $100 \mathrm{nM})$, or both. When cells were treated with both ADI and GEM, the cells were first treated with ADI $(0$, or $1.0 \mathrm{mU} / \mathrm{mL})$ for $12 \mathrm{~h}$, followed by $100 \mathrm{nM}$ GEM for another $12 \mathrm{~h}$. After a total of $24 \mathrm{~h}$ of treatment, cells were cultured in DMEM and incubated under optimal culture conditions for 14 days, fixed with methanol, and stained with $0.1 \%$ crystal violet. Visible colonies were manually counted and photographed.

\section{Detection of cell apoptosis}

Apoptosis was analyzed by three methods: 1) Flow cytometry: Apoptotic cells were analyzed using the Annexin-VFITC/PI kit (BD, San Diego, USA) by a FACSCalibur flow cytometer (BD) according to the manufacturer's instructions. Briefly, cells $\left(2 \times 10^{5} /\right.$ well $)$ were cultured in 6-well plates in the appropriate medium for $6 \mathrm{~h}$ prior to treatment with GEM (100 nM) and/or ADI (1 mU). Following incubation for the indicated times, cells were trypsinized and centrifuged, washed with PBS, and stained with Annexin V and PI in the dark. Samples were analyzed, and the percentage of apoptotic cells was evaluated. 2) In situ Annexin V/PI staining: Following the pretreatment as indicated in the flow cytometry, cells were washed with PBS and stained with $5 \mu \mathrm{L}$ of anti-Annexin V-FITC and $5 \mu \mathrm{L}$ of PI in $500 \mu \mathrm{L}$ of binding buffer in the dark for $15 \mathrm{~min}$ and then examined using a fluorescence microscope. 3) Hoechst 33258/PI double staining: After treatment as indicated previously, cells were washed with PBS and stained with $0.1 \mathrm{~mL}$ of Hoechst 33258 (Beyotime Biotechnology, Nantong, China) and PI for $15 \mathrm{~min}$. Stained cells were photographed under a fluorescence microscope.

\section{Cell cycle assay}

Cells were harvested after treatment at different time points, and they were resuspended in PBS. The cells were then fixed in $2 \mathrm{~mL}$ of $70 \%$ ethanol and incubated on ice for $30 \mathrm{~min}$, before being washed and treated with RNase A (100 $\mu \mathrm{g} / \mathrm{mL}, 5 \mathrm{~min})$ and stained with PI $(50 \mu \mathrm{g} / \mathrm{mL}, 15 \mathrm{~min})$. Cellular DNA content was analyzed in a Coulter Epics XL flow cytometer (Beckman-Coulter, Villepinte, France).

\section{NF-KB p65 nuclear translocation assay}

After the drug treatment, the cells were incubated with the NF- $к B$ p65 (C-20, Santa Cruz Biotechnology) antibody overnight. The subsequent processing was similar to the immunofluorescence assay. At the final step, the nuclear translocation of NF- $\mathrm{kB}$ p65 was viewed using a confocal scanning microscope (Leica).

\section{Tumorigenicity in a mouse xenograft model}

Six- to eight-week-old male BALB/c athymic mice were kept under pathogen-free conditions according to institutional guidelines. Each aliquot of approximately $1.0 \times 10^{7}$ PANC-1 pancreatic cancer cells suspended in $100 \mu \mathrm{L}$ of PBS containing 20\% of Growth Factor Reduced Matrigel (Becton Dickinson Labware, Flanklin, NJ, USA) was implanted subcutaneously into the mouse flank to establish xenograft tumors. After two weeks, the mice were randomly grouped into 4 groups with six animals in each group. Mice were intraperitoneally administered either PBS (vehicle), ADI (2 U/mouse), or GEM (100 mg/kg) alone or a combination of both ADI and GEM in $100 \mu \mathrm{L}$ of PBS every four days. The tumor size was measured every three days and the tumor volume (in $\mathrm{mm}^{3}$ ) was calculated using the formula $\mathrm{V}=0.4 \times \mathrm{D} \times \mathrm{d}^{2}(\mathrm{~V}$, volume; $\mathrm{D}$, longitudinal diameter; $d$, latitudinal diameter). Four weeks later, the mice were sacrificed and the tumors were excised and weighed. All animal experiments were conducted according to a protocol approved by the Institutional Animal Care and Use Committee of Xian Jiaotong University.

\section{Statistical analysis}

Statistical analyses were performed using the SPSS software (version 16.0, SPSS Inc. Chicago, USA). Experimental data in vitro and in vivo were expressed as mean \pm standard deviation (SD), and were analyzed by the Student's unpaired t-test or one-way ANOVA. For frequency distributions, a $X^{2}$ test was used with modification by the Fisher's exact test to account for frequency values less than 5. $P<0.05$ was considered statistically significant.

\section{Results}

Expression of ASS in pancreatic cancer cells and tissue The mRNA expression levels of ASS, a key factor that determines sensitivity to arginine deprivation via ADI, were measured in several cancer cell lines, including pancreatic cancer, breast cancer (low ASS-deficient tumor 
[37]), and HCC (high ASS-deficient tumor [37,38]) using qRT-PCR. The MCF-7 breast cancer cell line was used as a standard control for identifying ASS mRNA expression. The BxPC-3 (primary pancreatic cancer), SW1990 (spleen metastatic pancreatic cancer), BT474 (breast cancer), and HepG2 (HCC) cells expressed high levels of ASS mRNA and the PANC-1 (primary pancreatic cancer), MIA PaCa2 (primary pancreatic cancer), and MDA-MB-231 (breast cancer) cells expressed low levels of ASS relative to MCF7 cells (Figure 1A). The MDA-MB-453 (breast cancer) and MHCC97-H (HCC) cell lines expressed similar ASS mRNA levels as MCF-7 cells. Next, the expression level of ASS protein was evaluated by western blot assay in the four pancreatic cancer cell lines. The ASS protein expression pattern was similar to the ASS mRNA expression pattern in these cells (Figure 1C). Immunofluorescence analysis verified that ASS protein was located in the cytoplasm of BxPC-3 and SW1990 pancreatic cancer cells, and similar to the qRT-PCR and western blotting results, PANC-1 and MIA PaCa-2 cells did not express substantial ASS protein in situ (Figure 1B). Furthermore, we analyzed the levels of ASS protein in 14 fresh-frozen pancreatic cancer tissue samples by western blotting and found that pancreatic cancers expressed low levels of the ASS protein (7 with ASS expression deficiency) (Figure 1D). Nine of fourteen tissue specimens were extracted for detection of ASS mRNA level, and the results show that transcriptional levels of the ASS gene were similar to its protein expression in the examined specimens (Figure 1E). Additionally, the expression of p65 (a subunit of heterodimeric NF-kB complexes) and caspase-3 (a proapoptotic protein) was evaluated in 14 pancreatic cancer tissue samples by western blotting, presenting that there was a constitutional expression of $\mathrm{p} 65$ and caspase-3 proteins in examined specimens, and high level of caspase- 3 expression was associated with low p65 expression $(r=-0.634, P=0.027$; Figure 1F).

\section{Expression of ASS is associated with unfavorable biological behaviours in pancreatic cancer}

To understand the clinical importance of ASS expression in primary human pancreatic cancer tissues, we evaluated ASS expression in human pancreatic cancer tissues by IHC method. ASS expression was detected in 19 of the 34 (56\%) specimens and results from 2 of those tissues are shown (Figure 1G, i-iv). Reduced ASS expression correlated with lymph node metastasis, and local invasion in patients with pancreatic cancer (Table 1). In addition, the expression of survivin, a member of the inhibitor of apoptosis protein (IAP) family, was also detected in the same cancer specimens, and its expression was found in cytoplasm and/or nucleus in most of the cancer specimens (25/34, 74\%) (Figure 1G, v and vi). By comparing the expression of ASS and survivin in pancreatic cancer specimens, a positive correlation between reduced survivin and ASS expression was exhibited (Table 2).

\section{Effect of ADI on the growth, apoptosis, and cell cycle of pancreatic cancer cells}

Next, we examined the cytotoxic effect of ADI on BxPC3, SW1990, MIA PaCa-2, and PANC-1 cells by the MTT assay. Following treatment for one to three days, ADI significantly decreased the viability of ASS-deficient PANC-1 and MIA PaCa- 2 cells in a dose- and timedependent manner, but did not inhibit the proliferation of ASS-expressing BxPC-3 and SW1990 (Figure 2A). The $50 \%$ inhibitory concentration $\left(\mathrm{IC}_{50}\right)$ of $\mathrm{ADI}$ in PANC-1 was determined to be $1 \mathrm{mU} / \mathrm{mL}$ at $72 \mathrm{~h}$ and was used as the treatment dose in ensuing experiments. Subsequently, primary pancreatic cancer cell lines PANC-1 and BxPC-3 were used in further cellular and molecular experiments. The two cell lines treated with ADI or PBS were analyzed for cell cycle progression and apoptosis using FACS analysis. The findings showed that $1 \mathrm{mU} / \mathrm{mL}$ of ADI induced PANC-1 cell cycle arrest at the G1 phase and with a shorter G2/M phase, but caused scarcely any delay at the respective cell cycle phase for the BxPC-3 cell line at $24 \mathrm{~h}$ (Figure 2B). Similarly, $1 \mathrm{mU} / \mathrm{mL}$ ADI induced significant programmed cell death in ASS-deficient PANC-1 cells at 24, 48, and 72 $\mathrm{h}$ following treatment (Figure $2 \mathrm{C}$ ), but did not cause apoptosis in ASS-positive BxPC-3 cells at $48 \mathrm{~h}$ (Figure 2D). In addition, the cellular morphology of PANC-1 cells was altered (Figure 2E) and the colony formation ability was attenuated upon treatment with $1 \mathrm{mU} / \mathrm{mL}$ of ADI (Figure 2F), but these cellular changes were not observed in BxPC-3 cells.

\section{Regulatory role of ADI on the expression of apoptosis-related proteins, cell cycle protein cyclin D1, and phosphorylation of STAT3, AKT, and NF-кB p65}

To explore the precise mechanisms of ADI-induced apoptosis in pancreatic cancer cells, we studied several apoptosis-related proteins using western blotting. Our findings showed that, after $12 \mathrm{~h}$ treatment, ADI significantly downregulated the expression of two IAP-family antiapoptotic proteins, namely X-linked IAP (XIAP) and survivin (Figure $3 \mathrm{~A}$ ), and simultaneously upregulated the expression of caspase- 3 and caspase- 9 that are responsible for the release of mitochondrial proapoptotic proteins (Figure 3B) in PANC-1 cells; however, the same concentration of ADI treatment did not alter the expression of these apoptosis-related proteins in BxPC-3 cells (Figure 3D). Next, we found considerable accumulation of p53 protein in the p53-mutant PANC-1 (Figure 3C) and BxPC-3 (Figure 3E) cells, but p53 expression was not significantly altered after ADI treatment in either cell line, and no significant change in p21 protein (a p53 


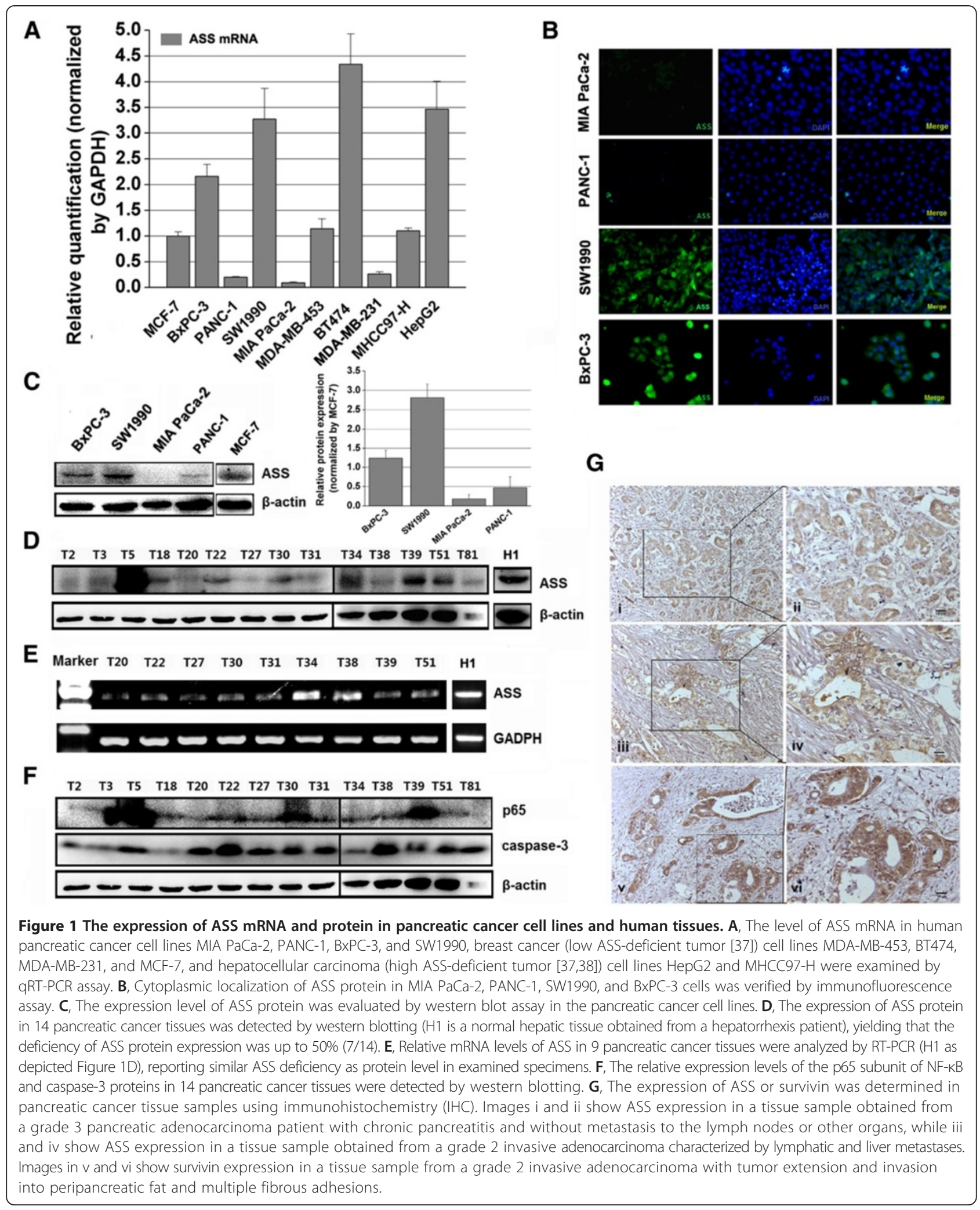


Table 1 Relation between clinical and histological characteristics of pancreatic cancer patients and ASS expression

\begin{tabular}{|c|c|c|}
\hline \multirow[t]{2}{*}{ Characteristics } & \multicolumn{2}{|c|}{ ASS } \\
\hline & Positive & Negative \\
\hline Median age (range) years & $63(47-78)$ & $68(44-83)$ \\
\hline Sex (male:female) & $11: 8$ & $10: 6$ \\
\hline \multicolumn{3}{|l|}{ Histological grade } \\
\hline । & $3(9 \%)$ & $2(6 \%)$ \\
\hline$\|$ & $12(35 \%)$ & $9(26 \%)$ \\
\hline III & $4(12 \%)$ & $4(12 \%)$ \\
\hline \multicolumn{3}{|l|}{ Tumor size $(\mathrm{cm})$} \\
\hline$\leq 3$ & $6(18 \%)$ & $3(9 \%)$ \\
\hline$>3-\leq 6$ & $10(29 \%)$ & $11(32 \%)$ \\
\hline$>6$ & $3(9 \%)$ & $1(3 \%)$ \\
\hline \multicolumn{3}{|l|}{ Pathologic stage } \\
\hline । & $3(9 \%)$ & $1(3 \%)$ \\
\hline$\|$ & $11(32 \%)$ & $8(24 \%)$ \\
\hline III & $2(6 \%)$ & $2(6 \%)$ \\
\hline IV & $3(9 \%)$ & $4(12 \%)$ \\
\hline \multicolumn{3}{|l|}{ Lymph node metastasis } \\
\hline Positive & $9(26 \%)$ & $13(35 \%)$ \\
\hline Negative & $10(29 \%)$ & $2(9 \%)^{*}$ \\
\hline \multicolumn{3}{|l|}{ Local invasion } \\
\hline Positive & $7(24 \%)$ & $12(29 \%)$ \\
\hline Negative & $12(32 \%)$ & $3(15 \%)^{*}$ \\
\hline
\end{tabular}

induced product) expression was detected. Due to no significant cellular and molecular changes in ASS-positive BxPC-3 pancreatic cancer cell after ADI treatment, we focused on the relevant studies in the ASS-negative PANC-1 cell line. After 0 to $24 \mathrm{~h}$ treatment with ADI, caspase-3 activation increased progressively in a timedependent fashion, while the expression of cyclin D1 was reduced in PANC-1 cells (Figure 4A). Furthermore, we tested the phosphorylation levels of p65 at serine 536 (p-p65 [Ser536]), shown to play a critical role in the activation of the NF- $\mathrm{KB}$ pathway $[39,40]$, in PANC-1 cells treated with ADI at several time points. We discovered that p-p65 (Ser536) decreased in a timedependent manner following ADI treatment (Figure 4B).

Table 2 Correlation between survivin expression and ASS expression

\begin{tabular}{llcc}
\hline & \multicolumn{2}{c}{ ASS } \\
\cline { 3 - 4 } & & Positive & Negative \\
\hline Survivin & Positive & $11(41 \%)$ & $14(41 \%)$ \\
& Negative & $8(15 \%)$ & $1(3 \%)^{*}$ \\
\hline${ }^{*} P<0.05$. & &
\end{tabular}

To understand whether ADI treatment blocked the phosphorylation of NF-kB p65 in PANC-1 cells via altering survival signaling, we detected the levels of Akt, p-Akt, ERK1/2, p-ERK1/2, STAT3, and p-STAT3. The results showed that ADI treatment for $8 \mathrm{~h}$ inhibited phosphorylation of STAT3 and Akt, but not ERK1/2 (Figure 4C).

\section{Effect of ADI on GEM-induced cytotoxicity in pancreatic cancer cells}

To evaluate the antiproliferative activity of ADI that potentiated GEM treatment, the MTT assay was initially conducted. The $\mathrm{IC}_{50}$ of GEM that inhibited the proliferation of BxPC-3 (Additional file 2: Figure S2A) and PANC-1 (Additional file 2: Figure S2B) cells was estimated by the MTT assay to be approximately $30 \mathrm{nM}$ and $100 \mathrm{nM}$ at $72 \mathrm{~h}$, respectively; this concentration was then used in the subsequent experiments. GEM in combined with $6 \mathrm{~h}$ ADI pretreatment significantly inhibited the proliferation of PANC-1 cells compared to ADI or GEM alone (Additional file 2: Figure S2D), but this effect was not observed in BxPC-3 cells (Additional file 2: Figure S2C). Furthermore, by using in situ fluorescence microscopy visualization (Figure 5A) and FACS (Figure 5B), it was revealed that ADI pretreatment for $6 \mathrm{~h}$ promoted GEM-induced PANC-1 cell apoptosis by $24 \mathrm{~h}$. We found that the apoptotic cells in situ readily stained with Annexin V-FITC/PI (green and red fluorescence) as well as with Hoechst and PI (blue and red fluorescence) (Figure 5A). Additionally, the GEM mediated $\mathrm{S}$ phase-arrest was enhanced in the case of pretreatment with ADI for $6 \mathrm{~h}$ (Figure 5C). We conducted a colony formation assay to test the colony-formation potential of individual PANC-1 cells; the results showed that GEM in combination with ADI pretreatment for $6 \mathrm{~h}$ reduced the colony numbers of PANC-1 cells compared to GEM or ADI alone (Figure 5D).

\section{Effect of ADI on the transcription levels of apoptosis-related genes}

To further understand the molecular changes associated with ADI-mediated potentiation of GEM-induced apoptosis in PANC-1 cells, we examined the mRNA levels of Bax, Bcl-2, caspase-3, and -9, and survivin in the cells by qRT-PCR. As shown in Figure 6A, both ADI and GEM upregulated Bax, caspase- 3 and -9 mRNA levels; GEM induced the mRNA level of the antiapoptotic gene Bcl-2; while ADI not only decreased the expression of $\mathrm{Bcl}-2$ but also inhibited the induction of $\mathrm{Bcl}-2$ transcription by GEM (with ADI pretreatment for $6 \mathrm{~h}$ ). Additionally, ADI downregulated survivin mRNA, while GEM had limited impact on survivin gene transcription; however, the combination of ADI pretreatment for $6 \mathrm{~h}$ with GEM resulted in even greater inhibition of survivin expression than ADI alone. 


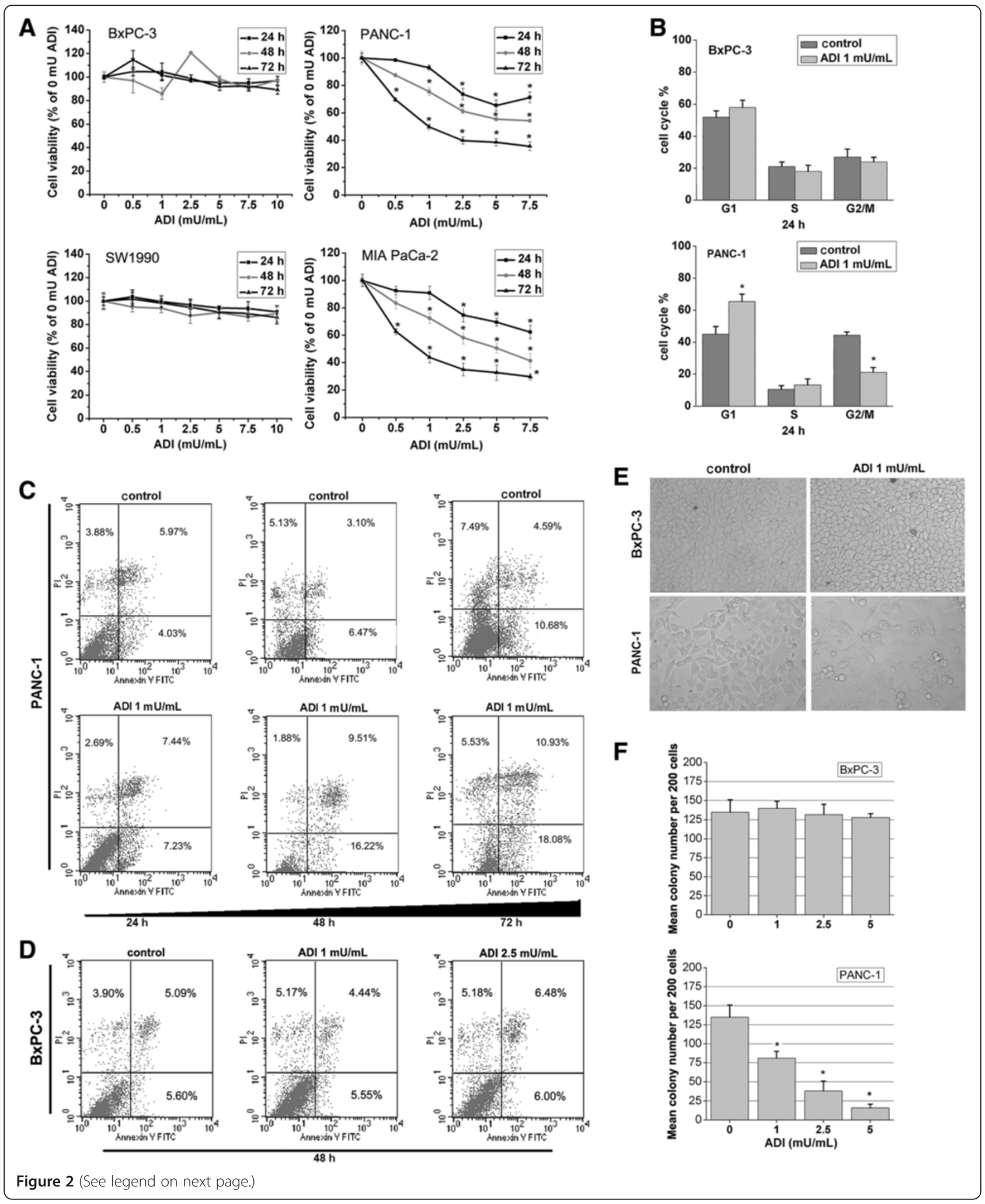


(See figure on previous page.)

Figure 2 The effect of ADI on the cell proliferation, apoptosis, cell cycle, and colony formation of pancreatic cancer cells. A, The proliferation-inhibitory effect of ADI on BXPC-3, PANC-1, SW1990, and MIA PaCa-2 cells was measured by the MTT assay. ${ }^{*}$, $P<0.05$ as compared with the control group $(0 \mathrm{mU} / \mathrm{mL}$ ADI). B, Cell cycle progression of primary pancreatic cancer cell lines BxPC-3 and PANC-1 after treatment with or without ADI was analyzed by FACS. ${ }^{*}, P<0.05$ as compared with the control group $(0 \mathrm{mU} \mathrm{ADI} / \mathrm{mL})$; NS, not significant. $\mathbf{C}$, The percentage of apoptotic PANC-1 cells treated with ADI was calculated by FACS. D, The percentage of apoptotic BxPC-3 cells treated by ADI for $48 \mathrm{~h}$ was calculated by FACS. E, ADI (1 mU/mL) intervention altered cell morphology of PANC-1 cells but not BxPC-3 cells. F, The colony forming ability of PANC-1 cells was altered by $\mathrm{ADI}$ intervention, while BxPC-3 colony formation was not changed. ${ }^{*}, P<0.05$ as compared with the control group ( $0 \mathrm{mU} \mathrm{ADI} / \mathrm{mL}$ ).

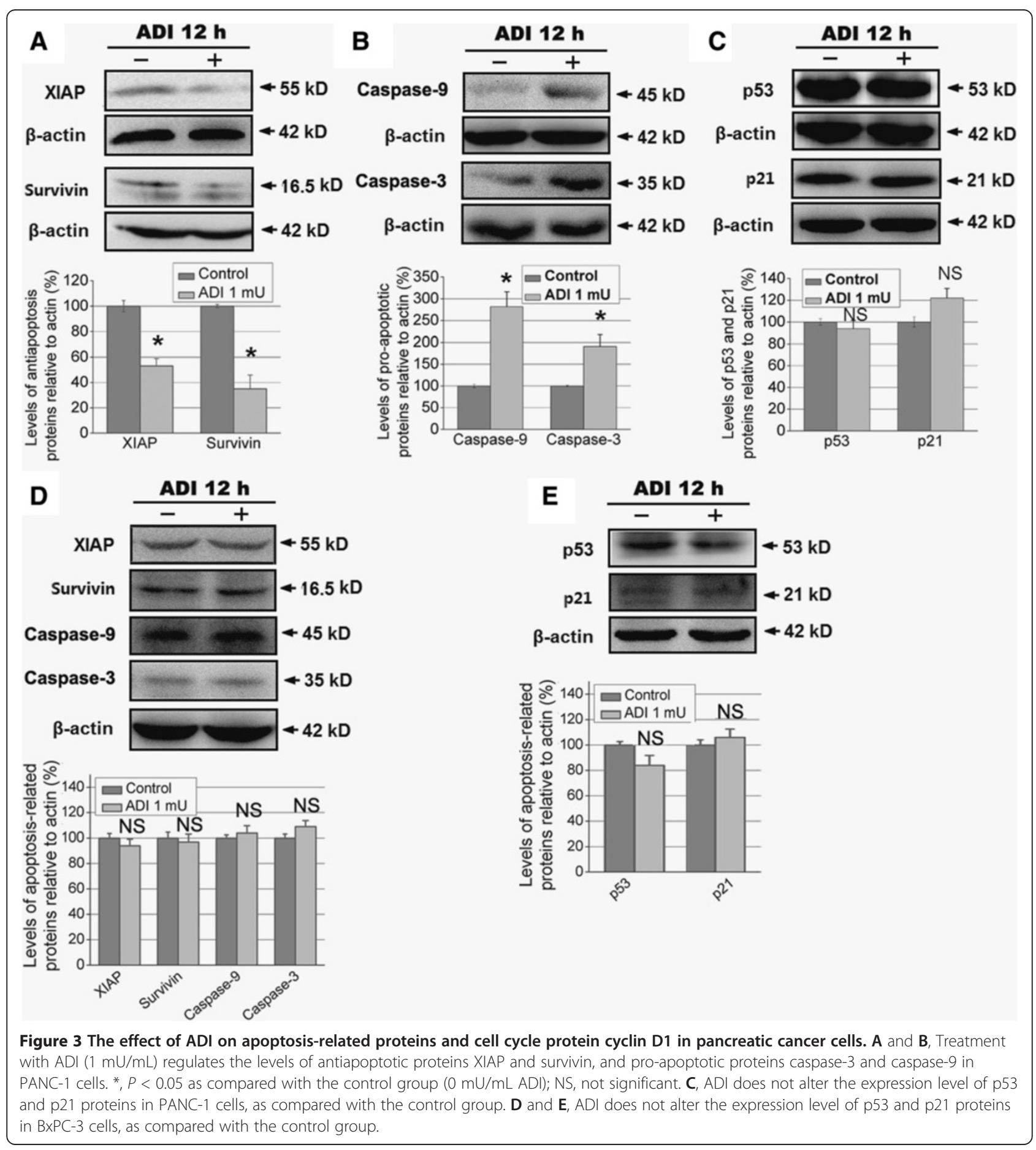




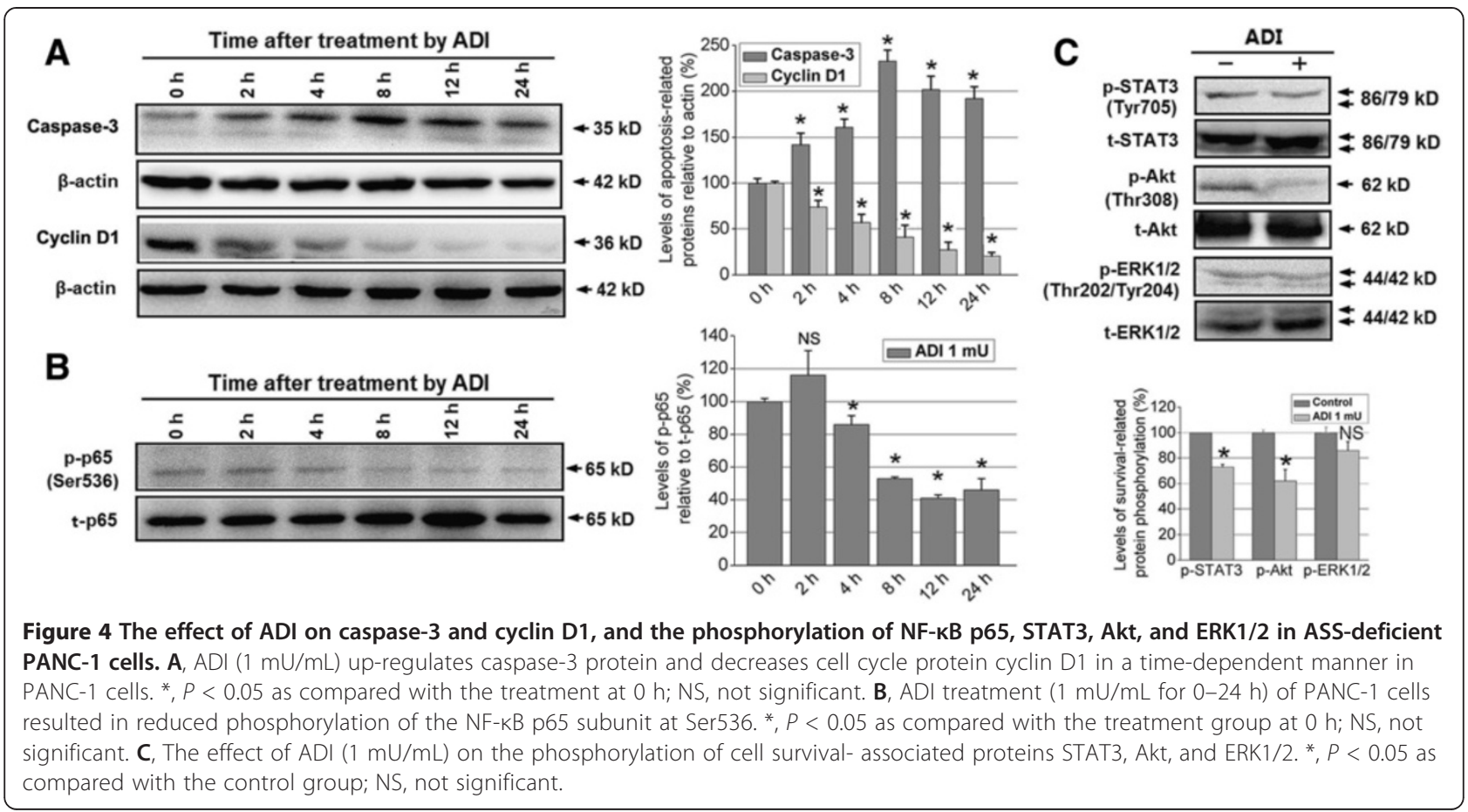

ADI suppresses phosphorylation (serine 536) and nuclear translocation of NF-kB p65 protein

We next determined whether ADI potentiated the GEMinduced apoptosis of PANC-1 cells by blocking activation of the NF- $\mathrm{B}$ p pathway. We found that ADI pretreatment for $6 \mathrm{~h}$ downregulated the nuclear expression of p65 and inhibited p65 induction by GEM (Figure 6B). Next, we studied whether ADI inhibited the GEM-induced p65 nuclear translocation in PANC-1 cells using in situ immunofluorescence microscopy. As shown in Figure 6C, p65 was located in the cytoplasm in the control group and in the ADI-treated group, while a significant amount of p65 was visible in the nucleus as green fluorescent spots in the GEM-treated group. However, when PANC-1 cells treated with both GEM and the pretreatment ADI for $6 \mathrm{~h}$, the green fluorescent nuclear spots of p65 disappeared, indicating that ADI can block the nuclear translocation of the NF-kB p65 subunit. To evaluate whether ADI regulates GEM-induced activation of NF- $\mathrm{B}$ pathway by inhibiting p65 phosphorylation, we examined the ratio of p-p65 (Ser536) to total p65 in nuclear and cytoplasmic extracts. Our analysis of the nuclear proteins showed that ADI significantly decreased p-p65 expression levels, while GEM did not. Additionally, ADI pretreatment reduced p-p65 levels in combination with GEM. In the cytoplasmic extracts, GEM significantly increased p-p65 expression which was unaffected by ADI alone, but significantly reduced in ADI pretreatment combined with GEM (Figure 6D). Together, these data provide evidence that
ADI can suppress NF- $\mathrm{kB}$ pathway activation. Furthermore, GEM alone induced c-Jun phosphorylation at Ser73, but ADI alone or together with GEM did not. However, ADI pretreatment for $6 \mathrm{~h}$ could decrease the p-c-Jun induction by GEM alone, indicating that ADI could maintain c-Jun phosphorylation at the baseline level (Figure 6E). Finally, we validated the expression of survivin protein in nuclear extracts and found results similar to that for mRNA expression inhibited by ADI treatment; however, GEM increased the expression of nuclear survivin (Figure 6F).

\section{ADI blocks NF-KB p65 phosphorylation (serine 536) via} inactivating $\mathrm{PI} 3 \mathrm{~K} / \mathrm{Akt}$ survival signal pathway

To understanding whether ADI down-regulated the phosphorylation of NF-kB p65 by blocking activation of the PI3K/Akt survival signal pathway, we evaluated the expression of several important proteins in this signaling pathway in pancreatic cancer cells treated with ADI in combination with the PI3K inhibitor LY294002 treatment for $20 \mathrm{~min}$. The results showed that ADI combined with LY294002 at $20 \mu \mathrm{M}$ significantly downregulated the level of p-Akt (Thr308) and p-p65 (Ser536), but not p-ERK1/2 (Thr202/Tyr204) in ASS-deficient PANC-1 cells, as compared to ADI treatment alone $(P<0.05)$ (Figure 7A); however, the combined treatment of ADI and LY294002 did not change the expression of relevant proteins of the PI3K/Akt and NF-kB p65 signaling pathways as compared with $\mathrm{ADI}$ treatment alone, in ASS-positive BxPC-3 pancreatic cancer cells (Figure 7B). 


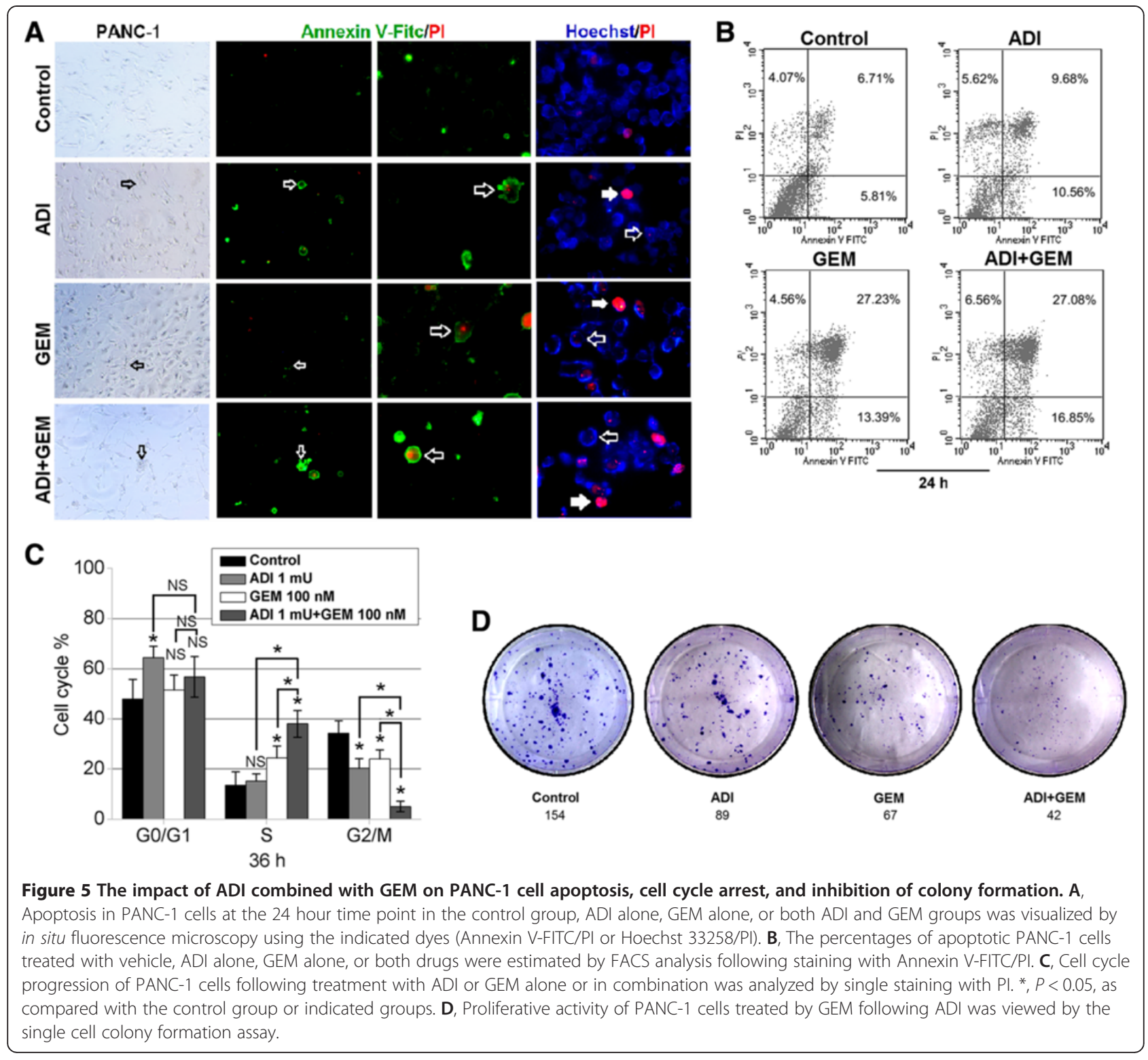

ADI augments GEM-mediated inhibition of tumorigenesis of PANC-1 pancreatic cancer cells in vivo

Based on our findings that ADI blocks NF- $\mathrm{kB}$ signaling, leading to enhance GEM-induced apoptosis of PANC-1 cells in vitro, we thus sought that it would be interesting to determine if ADI enhanced the antitumor effect of GEM in vivo. For these studies, PANC-1 cells were subcutaneouly implanted into nude mice to generate a xenograft. When the xenograft tumors had grown to approximately $50 \mathrm{~mm}^{3}$, the mice $(\mathrm{n}=6)$ were treated with PBS (vehicle), ADI (2 U/mouse), GEM (100 mg/kg), or both ADI and GEM. The tumors regressed during the treatment period in all groups except the vehicle group (Figure 8A and B). From days 15-24, treatment with both ADI and GEM markedly regressed tumor growth when compared to GEM or ADI alone, and minimal tumors were observed in the combination group at resection (Figure 8B).

\section{Discussion}

In this report, we show that reduced ASS expression is correlated with unfavorable tumor behaviors in patients with pancreatic cancer, and arginine deprivation by ADI can effectively induce programmed cell death in PANC1 cells with undetectable ASS expression, and also sensitize pancreatic cancer cells to GEM, a first-line chemotherapy in pancreatic cancer. In addition, we demonstrate the mechanism by which ADI augments the sensitivity of ASS-deficient pancreatic cancer cells to GEM treatment. Our findings show that ADI alone results in down-regulation of IAP family member survivin and XIAP, and induces caspase-dependent apoptosis. 


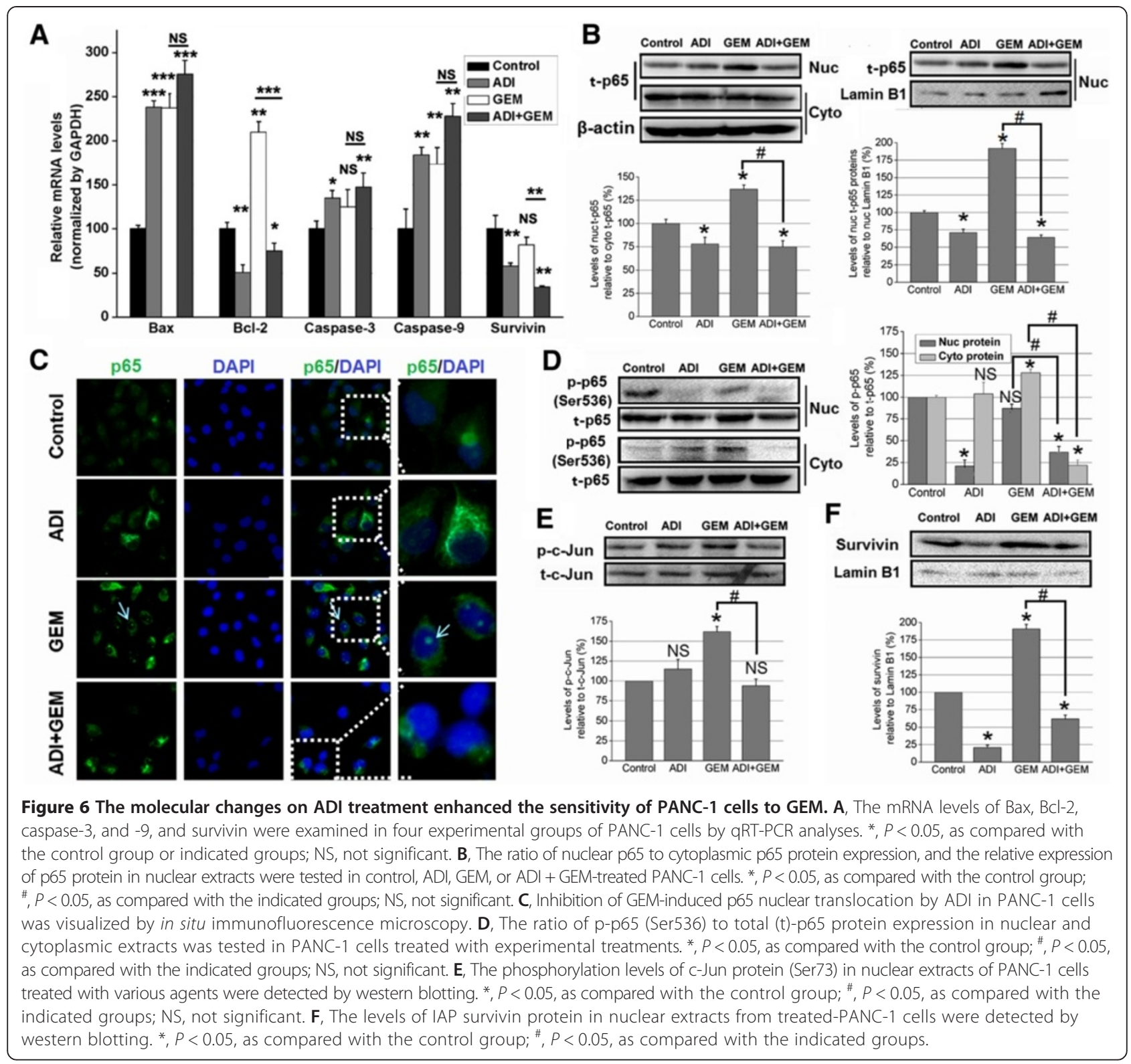

Furthermore, ADI may block PI3K/Akt and STAT3 survival signaling to exhibit antitumor effects. By blocking PI3K/Akt signaling and suppressing NF- $\mathrm{kB}$ activation via inhibition of the nuclear translocation and phosphorylation (serine 536) of nuclear NF-kB p65, ADI displays a highly significant synergism in anticancer activities against pancreatic cancer cells deficient in ASS expression in combination with GEM (Figure $8 \mathrm{C}$ ). Thus, the present study offers a new treatment strategy for pancreatic cancer involving arginine depletion.

ADI has been reported to have antitumor activity, it is antiangiogenic, and it synergizes to promote dexamethasoneinduced cytotoxicity $[10,14,15,41-43]$. As described in previous studies cancer cells are sensitive to the antiproliferative activity of ADI arginine deprivation, which correlates with the endogenous arginine metabolic enzyme, ASS $[10,13,15]$. Here, we found that the majority of human pancreatic cancer specimens have a low expression of ASS, and reduced ASS expression was associated with unfavorable histopathological characteristics of pancreatic cancer. In four of the pancreatic cancer cell lines that were examined, the ASS mRNA levels by qRT-PCR assay were similar as previously reported, but expression in SW1990 was not detected (Figure 1A); as a pilot study on ADI apply to treatment for pancreatic cancer, this work demonstrated the effect of PEG-ADI on cell growth inhibition and apoptosis induction in MIA PaCa-2 pancreatic cancer cells [15]. However, the study was worthwhile to understand the precise mechanism of ADI-induced pancreatic cancer cell growth inhibition and apoptosis induction. 


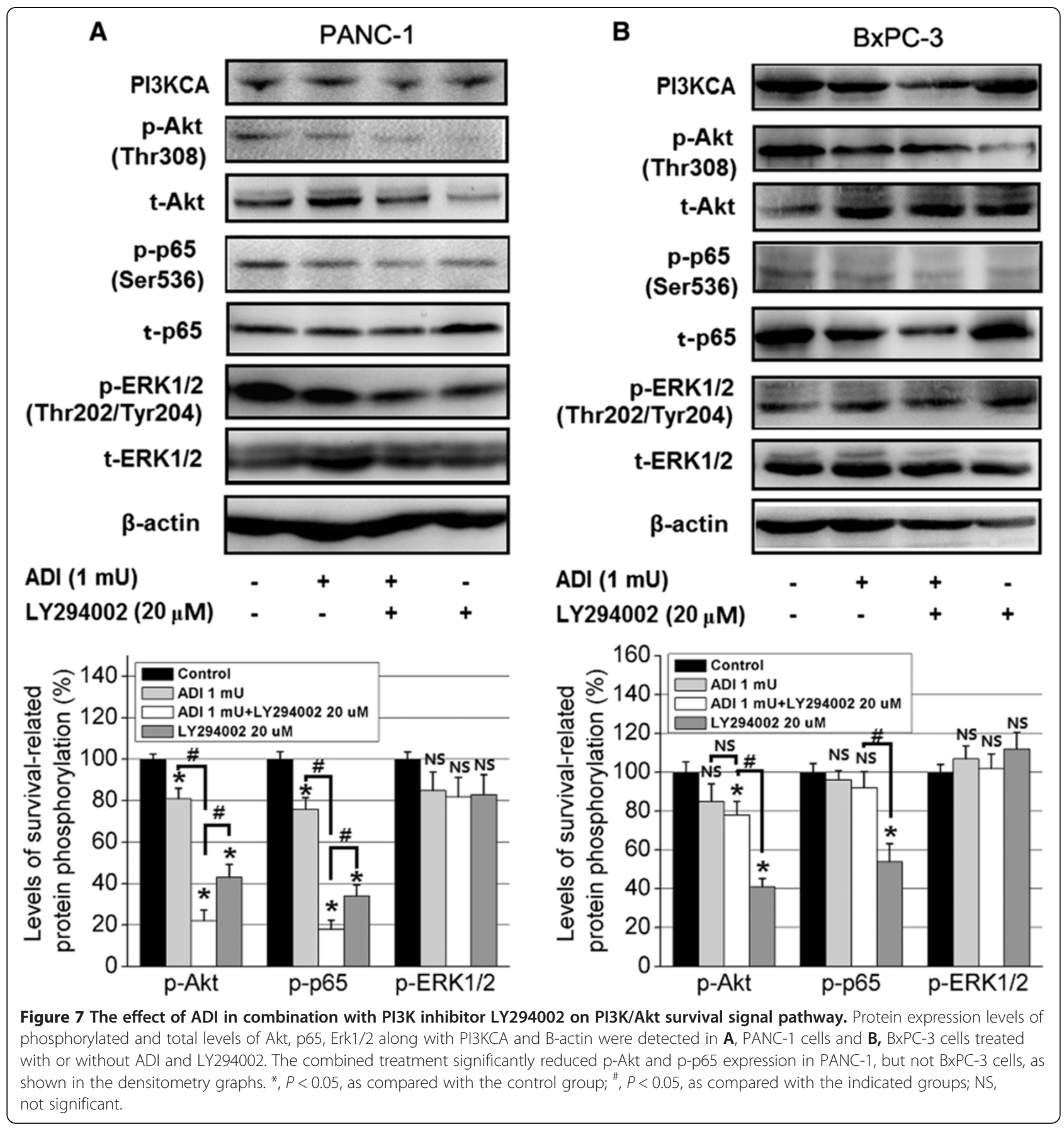

The present study contributed to our understanding of some of the signaling mechanisms regulated by ADI in ASS-deficient PANC-1 cells. Naturally, our results are likely to be generally applicable to other pancreatic cancer cells that lack ASS expression, other than the cell lines used in this study.

A number of studies demonstrate that GEM treatment can induce NF- $\kappa B$ signal activation $[23,44]$. NF- $\kappa B$ activation is involved in the inhibition of apoptosis, induction of mitogenic gene products such as cyclin D1, increased expression of proangiogenic factors, and regulation of gene products that promote migration and invasion of pancreatic cancer cells, which together contribute to the chemoresistance of pancreatic cancer [45-49]. By arginine depletion, ADI causes metabolic stress in arginine auxotrophic cells, which could compliment conventional GEM-based chemotherapies that are largely based on genotoxic stress. In our report, fourteen pancreatic cancer specimens had varying expression levels of NF-kB p65 and showed an inverse correlation with the expression of 


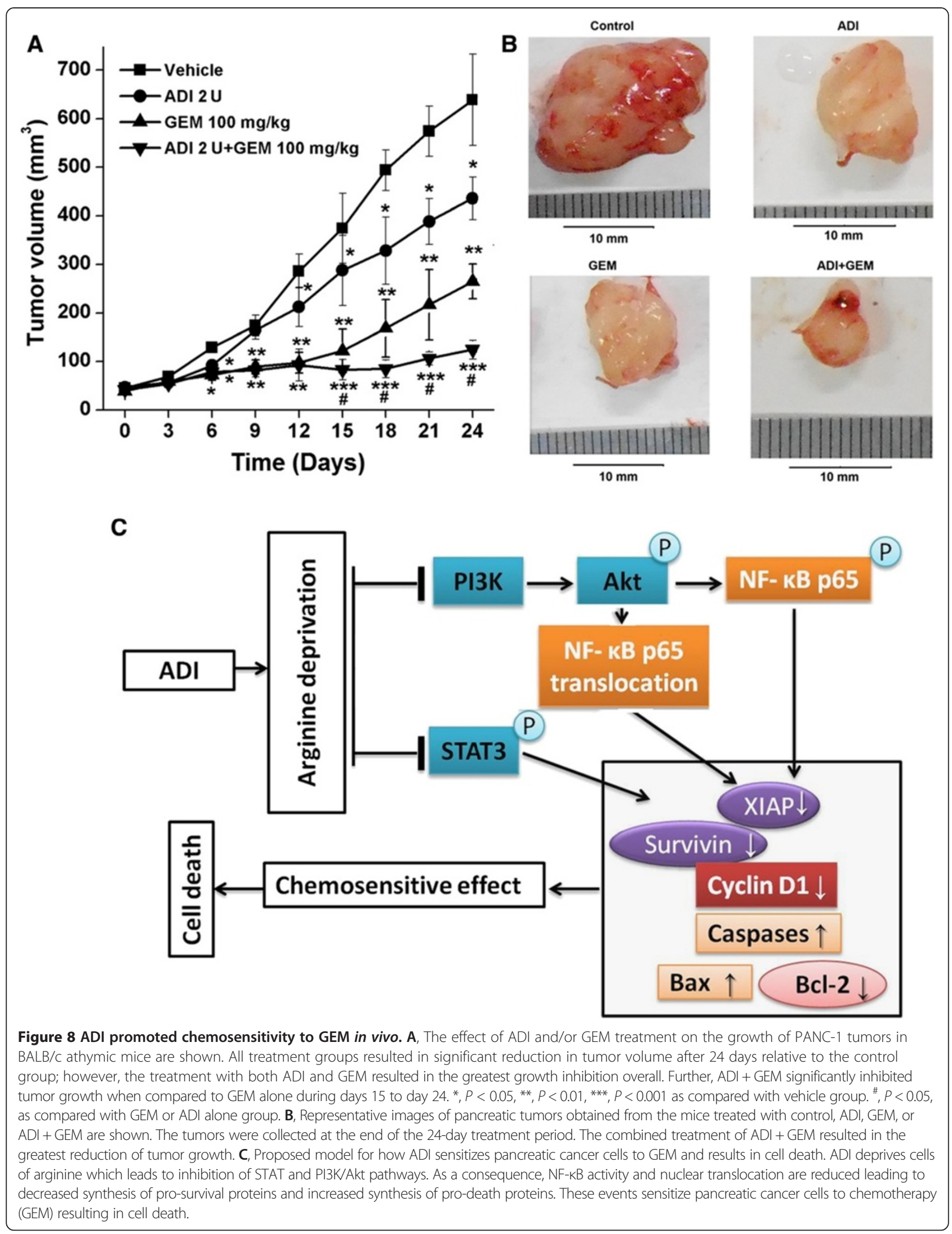


caspase-3. Our in vitro studies showed that ADI upregulates many proapoptotic factors, such as Bax, caspase-3 and -9 , and simultaneously downregulates antiapoptotic gene products, $\mathrm{Bcl}-2$, XIAP, and survivin, but not p53 and p21, indicating that ADI promoted apoptosis in PANC-1 cells in part via caspase activation and suppression of IAPs. ADI treatment blocked the phosphorylation of NF- $\kappa B$ p65 subunit. With the combination therapy of ADI and GEM, we found that ADI obstructs the GEMmediated NF-kB p65 protein translocation into the nucleus where NF- $\mathrm{kB}$ binds with various genes and activates their transcription [50-52]. By suppressing p65 subunit nuclear translocation and phosphorylation at Ser536, the two NF-kB activation pathways $[25,26,39,40]$, ADI reduces chemoresistance, producing a synergism on with GEMinduced programmed cell death in PANC-1 pancreatic cancer cells. Moreover, a preliminary animal experiment also validated the synergism of ADI with the antitumor effect of GEM in vivo. Our study provides the first data suggesting that ADI enhances the chemosensitivity to GEM by suppression of NF-kB p65 nuclear translocation and phosphorylation of nuclear p65 subunit, and thus, the work described here offers a new treatment option for pancreatic cancer.

Multiple signals regulate or synergize with NF- $\mathrm{kB}$ pathway activation, such as PI3K/Akt [25,26], STAT3 [45], and MAPK/ERK1/2 [53,54]. We explored whether ADI alters the phosphorylation levels of cell survival-associated signaling pathway proteins, including Akt, STAT3, and ERK1/2. Our findings revealed that ADI reduced p-Akt and p-STAT3 levels, but not p-ERK1/2. Based on our experiments with ADI treatment alone, we postulate that ADI may obstruct nuclear translocation of NF-kB p65 subunit and downregulate nuclear p65 phosphorylation at Ser536 via suppression of PI3K/Akt signaling under metabolic stress by arginine depletion. Indeed, the molecular studies in pancreatic cancer cells verified this hypothesis.

\section{Conclusion}

Although GEM-based chemotherapies are currently the standard of care for the treatment of advanced pancreatic cancer, its efficacy is limited because pancreatic cancer cells are often resistant to GEM through a mechanism that involves NF- $\mathrm{KB}$ activation. In this context, our findings suggest that reduced ASS expression predicts unfavorable tumor behaviours, while in ASS-deficient PANC-1 cells, ADI enhances their chemosensitivity to GEM-induced apoptosis. The mechanism by which ADI synergized with GEM involved inhibiting PI3K/Akt/NF-kB signaling, as evidenced by NF-kB pathway inactivation via the suppression of nuclear translocation and phosphorylation of the p65 subunit at Ser536. Therefore, the combination of ADI and GEM is advantageous because of their complementary action, and will offer a novel treatment strategy for pancreatic cancer.

\section{Additional files}

\begin{abstract}
Additional file 1: Figure S1. The proteinogram of heat-denatured ADI protein from M. arginini. The ADI gene was cloned from M. arginini genomic DNA and recombinant ADI was overexpressed and purified as previously described [31]. The molecular weight of purified ADI was observed to be $46 \mathrm{kDa}$.

Additional file 2: Figure S2. ADI sensitizes pancreatic cancer cells to GEM-induced growth inhibition. A, GEM inhibited the proliferation of BXPC -3 cells at continuous concentrations estimated by the MTT growth assay. B, GEM inhibited the proliferation of PANC-1 cell growth estimated by the MTT growth assay. $\mathbf{C}, \mathrm{ADI}$ in combination with GEM did not increase the inhibition ratio of proliferation in BXPC-3 cells more than that of treatment with GEM alone. D, ADI in combination with GEM significantly increased the inhibition ratio of proliferation in PANC-1 cells compared to treatment with $\mathrm{ADI}$ or GEM alone. ${ }^{*} P<0.05$, ${ }^{* *} P<0.01,{ }^{* * *} P<0.001$ as compared with control group or indicated groups.
\end{abstract}

\section{Abbreviations}

ADI: Arginine deiminase; Akt: Protein kinase B; ASS: Argininosuccinate synthetase; ATCC: American Type Culture Collection; BCA: Bicinchoninic acid; c-Jun: A member of activating protein 1 family; DAB: 3,3-diaminobenzidine tetrahydrochloride; DAPI: Diamidino-2-phenylindole;

DMSO: Dimethylsulfoxide; ERK1/2: Extracellular signal-regulated kinases 1 and 2; GAPDH: Glyceraldehyde-3-phosphate dehydrogenase; GEM: Gemcitabine; HCC: Hepatocellular carcinoma; IAP: Inhibitor of apoptosis protein; IHC: Immunohistochemical; MAPK: Mitogen-activated protein kinase; MTT: Methyl thiazolyl tetrazolium; NF-kB: Nuclear factor-kB; PI: Propidium iodide; PI3K: Phosphatidylinositol-3-kinase; qRT-PCR: Quantitative-real time reverse transcription polymerase chain reaction; Ser: Serine; STAT3: Signal transducer and activator of transcription 3; Thr: Threonine; Tyr: Tyrosine; XIAP: X-linked IAP

\section{Competing interests}

The authors declare that they have no competing interests.

\section{Authors' contributions}

Conception and design: J. Liu, Q. Ma, E. Wu. Development of methodology: J. Liu, J. Ma, Q. Ma, W. Li, D. Zhang, X. Wang, L. Han, F. Wang. Acquisition of data (provided cells, animals, acquired and managed patients, provided facilities, etc.): J. Liu, J. Ma, Q. Ma, Z. Wu, W. Li, D. Zhang, X. Wang, T. Shan, L. Han, S. Yu, F. Wang. Analysis and interpretation of data: J. Liu, Q. Ma, W. Li, D. Zhang, X. Wang, L. Han, F. Wang, E. Wu. Writing, review, and/or revision of the manuscript: J. Liu, Q. Ma, Z. Wu, W. Li, D. Zhang, L. Han, S. Yu, F. Wang, K. Reindl, E. Wu. Administrative, technical, or material support: Q. Ma, Z. Wu, L. Han. Study supervision: Q. Ma, Z. Wu, E. Wu. All authors read and approved the final manuscript.

\section{Acknowledgements}

The authors acknowledge the Dr. Hua Liang of the Department of Pathology, First Affiliated Hospital, Medical College and the staff of the Institution of Genetic Disease Research of Xi'an Jiaotong University for their technical assistance.

\section{Grant support}

This study was supported by grant from National Natural Science Foundation of China (Grant serial No. 81172360 for Q. Ma, 81301846 for W. Li and 81302153 for D. Zhang).

\section{Author details}

${ }^{1}$ Department of Hepatobiliary Surgery, First Affiliated Hospital, Medical college of Xi'an Jiaotong University, 277 West Yanta Road, Xi'an, Shaanxi 710061, China. ${ }^{2}$ Department of General Surgery, First Affiliated Hospital/ Cancer Institute, Henan University of Science and Technology, 24 Jinghua Road, Luoyang 471000, China. ${ }^{3}$ Department of Oncology, First Affiliated Hospital, Xi'an Jiaotong University, 76 West Yanta Road, 710061 Xi'an, China. 
${ }^{4}$ Department of Pharmaceutical Sciences, North Dakota State University, 58105 Fargo, ND, USA. ${ }^{5}$ Department of Biological Sciences, North Dakota State University, 58105 Fargo, ND, USA.

Received: 4 March 2014 Accepted: 10 September 2014

Published: 20 September 2014

\section{References}

1. Vincent A, Herman J, Schulick R, Hruban RH, Goggins M: Pancreatic cancer. Lancet 2011, 378(9791):607-620.

2. Siegel R, Ma J, Zou Z, Jemal A: Cancer statistics, 2014. CA Cancer J Clin 2014, 64(1):9-29.

3. Raimondi S, Maisonneuve P, Lowenfels AB: Epidemiology of pancreatic cancer: an overview. Nat Rev Gastroenterol Hepatol 2009, 6(12):699-708,

4. Cascinu S, Berardi R, Labianca R, Siena S, Falcone A, Aitini E, Barni S, Di Costanzo F, Dapretto E, Tonini G, Pierantoni C, Artale S, Rota S, Floriani I, Scartozzi M, Zaniboni A: Cetuximab plus gemcitabine and cisplatin compared with gemcitabine and cisplatin alone in patients with advanced pancreatic cancer: a randomised, multicentre, phase II trial. Lancet Oncol 2008, 9(1):39-44

5. Nakai Y, Isayama H, Sasaki T, Sasahira N, Tsujino T, Toda N, Kogure $H$, Matsubara S, Ito Y, Togawa O, Arizumi T, Hirano K, Tada M, Omata M, Koike K: A multicentre randomised phase II trial of gemcitabine alone vs gemcitabine and S-1 combination therapy in advanced pancreatic cancer: GEMSAP study. Br J Cancer 2012, 106(12):1934-1939.

6. Tuinmann G, Hegewisch-Becker S, Zschaber R, Kehr A, Schulz J, Hossfeld DK Gemcitabine and mitomycin $C$ in advanced pancreatic cancer: a single-institution experience. Anticancer Drugs 2004, 15(6):575-579.

7. Barbul A: Arginine: biochemistry, physiology, and therapeutic implications. JPEN J Parenter Enteral Nutr 1986, 10(2):227-238.

8. Ensor CM, Holtsberg FW, Bomalaski JS, Clark MA: Pegylated arginine deiminase (ADI-SS PEG20,000 mw) inhibits human melanomas and hepatocellular carcinomas in vitro and in vivo. Cancer Res 2002, 62 (19):5443-5450.

9. Kelly MP, Jungbluth AA, Wu BW, Bomalaski J, Old LJ, Ritter G: Arginine deiminase PEG20 inhibits growth of small cell lung cancers lacking expression of argininosuccinate synthetase. Br J Cancer 2012, 106(2):324-332.

10. Yoon CY, Shim YJ, Kim EH, Lee JH, Won NH, Kim JH, Park IS, Yoon DK, Min BH: Renal cell carcinoma does not express argininosuccinate synthetase and is highly sensitive to arginine deprivation via arginine deiminase. Int J Cancer 2007, 120(4):897-905.

11. Kim RH, Coates JM, Bowles TL, McNerney GP, Sutcliffe J, Jung JU, Gandour-Edwards R, Chuang FY, Bold RJ, Kung HJ: Arginine deiminase as a novel therapy for prostate cancer induces autophagy and caspase-independent apoptosis. Cancer Res 2009, 69(2):700-708.

12. Takaku H, Takase M, Abe S, Hayashi H, Miyazaki K: In vivo anti-tumor activity of arginine deiminase purified from Mycoplasma arginini. Int J Cancer 1992, 51(2):244-249

13. Feun LG, Marini A, Walker G, Elgart G, Moffat F, Rodgers SE, Wu CJ, You M, Wangpaichitr M, Kuo MT, Sisson W, Jungbluth AA, Bomalaski J, Savaraj N: Negative argininosuccinate synthetase expression in melanoma tumours may predict clinical benefit from arginine-depleting therapy with pegylated arginine deiminase. Br J Cancer 2012, 106(9):1481-1485.

14. Shen $L J$, Beloussow K, Shen WC: Modulation of arginine metabolic pathways as the potential anti-tumor mechanism of recombinant arginine deiminase. Cancer Lett 2006, 231(1):30-35.

15. Bowles TL, Kim R, Galante J, Parsons CM, Virudachalam S, Kung HJ, Bold RJ: Pancreatic cancer cell lines deficient in argininosuccinate synthetase are sensitive to arginine deprivation by arginine deiminase. Int J Cancer 2008, 123(8):1950-1955.

16. Burris HR, Moore MJ, Andersen J, Green MR, Rothenberg ML, Modiano MR, Cripps MC, Portenoy RK, Storniolo AM, Tarassoff P, Nelson R, Dorr FA, Stephens CD, Von Hoff DD: Improvements in survival and clinical benefit with gemcitabine as first-line therapy for patients with advanced pancreas cancer: a randomized trial. J Clin Oncol 1997, 15(6):2403-2413.

17. Mukherjee S, Hurt CN, Bridgewater J, Falk S, Cummins S, Wasan H, Crosby T, Jephcott C, Roy R, Radhakrishna G, McDonald A, Ray R, Joseph G, Staffurth J, Abrams RA, Griffiths G, Maughan T: Gemcitabine-based or capecitabine-based chemoradiotherapy for locally advanced pancreatic cancer (SCALOP): a multicentre, randomised, phase 2 trial. Lancet Oncol 2013, 14(4):317-326.

18. Karnitz LM, Flatten KS, Wagner JM, Loegering D, Hackbarth JS, Arlander SJ, Vroman BT, Thomas MB, Baek YU, Hopkins KM, Lieberman HB, Chen J, Cliby
WA, Kaufmann SH: Gemcitabine-induced activation of checkpoint signaling pathways that affect tumor cell survival. Mol Pharmacol 2005, 68(6):1636-1644

19. Kagawa S, Takano S, Yoshitomi H, Kimura F, Satoh M, Shimizu H, Yoshidome H, Ohtsuka M, Kato A, Furukawa K, Matsushita K, Nomura F, Miyazaki M: Akt/mTOR signaling pathway is crucial for gemcitabine resistance induced by Annexin II in pancreatic cancer cells. J Surg Res 2012, 178(2):758-767.

20. Shrikhande SV, Kleeff J, Kayed H, Keleg S, Reiser C, Giese T, Buchler MW, Esposito I, Friess H: Silencing of X-linked inhibitor of apoptosis (XIAP) decreases gemcitabine resistance of pancreatic cancer cells. Anticancer Res 2006, 26(5A):3265-3273.

21. Singh S, Srivastava SK, Bhardwaj A, Owen LB, Singh AP: CXCL12-CXCR4 signalling axis confers gemcitabine resistance to pancreatic cancer cells: a novel target for therapy. Br J Cancer 2010, 103(11):1671-1679.

22. Bafna S, Kaur S, Momi N, Batra SK: Pancreatic cancer cells resistance to gemcitabine: the role of MUC4 mucin. Br J Cancer 2009, 101(7):1155-1161.

23. Arlt A, Gehrz A, Muerkoster S, Vorndamm J, Kruse ML, Folsch UR, Schafer H: Role of $\mathrm{NF}-$-kappaB and Akt/PI3K in the resistance of pancreatic carcinoma cell lines against gemcitabine-induced cell death. Oncogene 2003, 22(21):3243-3251.

24. Zheng $C$, Jiao $X$, Jiang $Y$, Sun S: ERK $1 / 2$ activity contributes to gemcitabine resistance in pancreatic cancer cells. J Int Med Res 2013, 41(2):300-306

25. Sizemore N, Leung S, Stark GR: Activation of phosphatidylinositol 3-kinase in response to interleukin-1 leads to phosphorylation and activation of the NF-kappaB p65/RelA subunit. Mol Cell Biol 1999, 19(7):4798-4805.

26. Madrid LV, Mayo MW, Reuther JY, Baldwin AJ: Akt stimulates the transactivation potential of the RelA/p65 Subunit of NF-kappa B through utilization of the Ikappa B kinase and activation of the mitogen-activated protein kinase p38. J Biol Chem 2001, 276(22):18934-18940.

27. Huang XY, Wang HC, Yuan Z, Li A, He ML, Ai KX, Zheng Q, Qin HL: Gemcitabine combined with gum mastic causes potent growth inhibition and apoptosis of pancreatic cancer cells. Acta Pharmacol Sin 2010, 31(6):741-745.

28. Kong R, Sun B, Jiang H, Pan S, Chen H, Wang S, Krissansen GW, Sun X Downregulation of nuclear factor-kappaB p65 subunit by small interfering RNA synergizes with gemcitabine to inhibit the growth of pancreatic cancer. Cancer Lett 2010, 291(1):90-98.

29. Pan X, Arumugam T, Yamamoto T, Levin PA, Ramachandran V, Ji B, LopezBerestein G, Vivas-Mejia PE, Sood AK, McConkey DJ, Logsdon CD: Nuclear factor-kappaB p65/relA silencing induces apoptosis and increases gemcitabine effectiveness in a subset of pancreatic cancer cells. Clin Cancer Res 2008, 14(24):8143-8151

30. Uwagawa T, Chiao PJ, Gocho T, Hirohara S, Misawa T, Yanaga K: Combination chemotherapy of nafamostat mesilate with gemcitabine for pancreatic cancer targeting NF-kappaB activation. Anticancer Res 2009, 29(8):3173-3178.

31. Beloussow K, Wang L, Wu J, Ann D, Shen WC: Recombinant arginine deiminase as a potential anti-angiogenic agent. Cancer Lett 2002, 183(2):155-162.

32. Miyazaki K, Takaku H, Umeda M, Fujita T, Huang WD, Kimura T, Yamashita J, Horio T: Potent growth inhibition of human tumor cells in culture by arginine deiminase purified from a culture medium of a Mycoplasma-infected cell line. Cancer Res 1990, 50(15):4522-4527.

33. Zhang $\mathrm{D}, \mathrm{Ma} \mathrm{QY}, \mathrm{Hu} \mathrm{HT}$, Zhang $\mathrm{M}$ : beta2-adrenergic antagonists suppress pancreatic cancer cell invasion by inhibiting CREB, NFkappaB and AP-1. Cancer Biol Ther 2010, 10(1):19-29.

34. Likhite N, Warawdekar UM: A unique method for isolation and solubilization of proteins after extraction of RNA from tumor tissue using trizol. J Biomol Tech 2011, 22(1):37-44.

35. Liu H, Ma Q, Li J: High glucose promotes cell proliferation and enhances GDNF and RET expression in pancreatic cancer cells. Mol Cell Biochem 2011, 347(1-2):95-101

36. Albrethsen J, Bogebo R, Gammeltoft S, Olsen J, Winther B, Raskov H: Upregulated expression of human neutrophil peptides 1, 2 and 3 (HNP 1-3) in colon cancer serum and tumours: a biomarker study. BMC Cancer 2005, 5:8.

37. Dillon BJ, Prieto VG, Curley SA, Ensor CM, Holtsberg FW, Bomalaski JS, Clark MA: Incidence and distribution of argininosuccinate synthetase deficiency in human cancers: a method for identifying cancers sensitive to arginine deprivation. Cancer 2004, 100(4):826-833.

38. Delage B, Fennell DA, Nicholson L, McNeish I, Lemoine NR, Crook T, Szlosarek PW: Arginine deprivation and argininosuccinate 
synthetase expression in the treatment of cancer. Int J Cancer 2010, 126(12):2762-2772.

39. Hu J, Nakano H, Sakurai H, Colburn NH: Insufficient p65 phosphorylation at $\mathrm{S} 536$ specifically contributes to the lack of NF-kappaB activation and transformation in resistant JB6 cells. Carcinogenesis 2004, 25(10):1991-2003.

40. Jiang X, Takahashi N, Matsui N, Tetsuka T, Okamoto T: The NF-kappa B activation in lymphotoxin beta receptor signaling depends on the phosphorylation of p65 at serine 536. J Biol Chem 2003, 278(2):919-926.

41. Gong H, Pottgen C, Stuben G, Havers W, Stuschke M, Schweigerer L: Arginine deiminase and other antiangiogenic agents inhibit unfavorable neuroblastoma growth: potentiation by irradiation. Int J Cancer 2003, 106(5):723-728.

42. Park IS, Kang SW, Shin YJ, Chae KY, Park MO, Kim MY, Wheatley DN, Min BH: Arginine deiminase: a potential inhibitor of angiogenesis and tumour growth. Br J Cancer 2003, 89(5):907-914.

43. Noh EJ, Kang SW, Shin YJ, Choi SH, Kim CG, Park IS, Wheatley DN, Min BH: Arginine deiminase enhances dexamethasone-induced cytotoxicity in human T-lymphoblastic leukemia CCRF-CEM cells. Int J Cancer 2004, 112(3):502-508.

44. Muerkoster S, Arlt A, Witt M, Gehrz A, Haye S, March C, Grohmann F, Wegehenkel K, Kalthoff H, Folsch UR, Schafer H: Usage of the NF-kappaB inhibitor sulfasalazine as sensitizing agent in combined chemotherapy of pancreatic cancer. Int J Cancer 2003, 104(4):469-476.

45. Greten FR, Weber CK, Greten TF, Schneider G, Wagner M, Adler G, Schmid RM: Stat 3 and NF-kappaB activation prevents apoptosis in pancreatic carcinogenesis. Gastroenterology 2002, 123(6):2052-2063.

46. Kunnumakkara AB, Guha S, Krishnan S, Diagaradjane P, Gelovani J, Aggarwal BB: Curcumin potentiates antitumor activity of gemcitabine in an orthotopic model of pancreatic cancer through suppression of proliferation, angiogenesis, and inhibition of nuclear factor-kappaB-regulated gene products. Cancer Res 2007, 67(8):3853-3861.

47. Liptay S, Weber CK, Ludwig L, Wagner M, Adler G, Schmid RM: Mitogenic and antiapoptotic role of constitutive NF-kappaB/Rel activity in pancreatic cancer. Int J Cancer 2003, 105(6):735-746.

48. Xiong HQ, Abbruzzese JL, Lin E, Wang L, Zheng L, Xie K: NF-kappaB activity blockade impairs the angiogenic potential of human pancreatic cancer cells. Int J Cancer 2004, 108(2):181-188.

49. Yebra M, Filardo EJ, Bayna EM, Kawahara E, Becker JC, Cheresh DA: Induction of carcinoma cell migration on vitronectin by NF-kappa B-dependent gene expression. Mol Biol Cell 1995, 6(7):841-850.

50. Loercher A, Lee TL, Ricker JL, Howard A, Geoghegen J, Chen Z, Sunwoo JB, Sitcheran R, Chuang EY, Mitchell JB, Baldwin AJ, Van Waes C: Nuclear factor-kappaB is an important modulator of the altered gene expression profile and malignant phenotype in squamous cell carcinoma. Cancer Res 2004, 64(18):6511-6523.

51. Ludwig L, Kessler H, Wagner M, Hoang-Vu C, Dralle H, Adler G, Bohm BO Schmid RM: Nuclear factor-kappaB is constitutively active in C-cell carcinoma and required for RET-induced transformation. Cancer Res 2001, 61(11):4526-4535.

52. Maldonado V, Melendez-Zajgla J, Ortega A: Modulation of NF-kappa B, and Bcl-2 in apoptosis induced by cisplatin in HeLa cells. Mutat Res 1997, 381(1):67-75.

53. Armstrong MB, Bian X, Liu Y, Subramanian C, Ratanaproeksa AB, Shao F, Yu VC Kwok RP, Opipari AW, Castle VP: Signaling from p53 to NF-kappa B determines the chemotherapy responsiveness of neuroblastoma. Neoplasia 2006, 8(11):964-974.

54. Weng CJ, Chau CF, Hsieh YS, Yang SF, Yen GC: Lucidenic acid inhibits PMA-induced invasion of human hepatoma cells through inactivating MAPK/ERK signal transduction pathway and reducing binding activities of NF-kappaB and AP-1. Carcinogenesis 2008, 29(1):147-156.

doi:10.1186/1471-2407-14-686

Cite this article as: Liu et al:: Arginine deiminase augments the chemosensitivity of argininosuccinate synthetase-deficient pancreatic cancer cells to gemcitabine via inhibition of NF-KB signaling. BMC Cancer 2014 14:686.

\section{Submit your next manuscript to BioMed Central and take full advantage of:}

- Convenient online submission

- Thorough peer review

- No space constraints or color figure charges

- Immediate publication on acceptance

- Inclusion in PubMed, CAS, Scopus and Google Scholar

- Research which is freely available for redistribution 